Research Paper

\title{
Learning History Using Augmented Reality
}

\section{Nur Ain Najihah Ibharim ${ }^{1}$, Siti Zalifah Ramli ${ }^{1}$, Siti Aishah Zahari ${ }^{1}$, Nur Amalia Atikah Edyanto $^{1}$, Muhammad Asyraf Abdullah Zawawi ${ }^{2}$}

${ }^{1}$ Program of Software Engineering, Department of Computing, Faculty of Art, Computing \& Creative Industry. Sultan Idris Education University, Malaysia.

${ }^{2}$ Program of Information Technology, Department of Computing, Faculty of Art, Computing \& Creative Industry. Sultan Idris Education University, Malaysia.

\author{
Article History \\ Received: \\ 30.01 .2021 \\ Revised: \\ 07.03.2021 \\ Accepted: \\ 14.03.2021 \\ *Corresponding Author: \\ Nur Ain Najihah Ibharim \\ Email: \\ urainnajihah502@gmail.com
}

This is an open access article, licensed under: $\mathrm{CC}-\mathrm{BY}-\mathrm{SA}$
Abstract: Nowadays, we can see at early in prime school has been revealed about the history of the homeland in the subject of history. At secondary school also, the subject of history is one of subject must pass in the Sijil Pelajaran Malaysia (SPM) examination. This means that knowledge about history is very important in our life as a guide and teaches us in how to progress and advance not making the same mistakes. We also must have deep knowledge about history of homeland so we can appreciate them and also make them all our idols. However, learning about history of homeland warrior can be challenging, especially for student who think that learning about history is boring and some student are less aware of the importance of studying history. To help teacher teach and also attract student to learn about history, try to use Augmented Reality for make learning session fun. The research aims to design an application for learning history of homeland using Augmented Reality. This research also fits the syllabus in school. This research use ADDIE Model to develop AR application as a guide because it is be flexible when innovate and suitable form of teaching design. In addition, quantitative methods through questionnaires were implemented to evaluate the research that were developed. The research was evaluated by 10 teachers who teach history lessons and 15 students from Sultan Idris Education University who studying in Bachelor of Education (History) with Honors, which evaluated based on usefulness, satisfaction and ease of use questionnaires.

Keywords: Augmented Reality, Educational Technology, Homeland Warrior, Multimedia, Subject of History. 


\section{Introduction}

Since 2013, the Ministry of Education has made history about there is a must-pass subject for all candidates who sit for the Malaysian Certificate of Education (SPM) examination. This is because the importance of this subject will be seen more in other perspective, such as endorsing a patriotism in student life and not just get the better result in certificate only. According to this, District Education Officer, Petaling Utama, Mr Azmi Misron said, "Students must change the perception that history is difficult to master but it is really need to understand clearly something that happened with all aspects of components, concepts, personalities, and so on". Therefore, everyone including school administrators, teachers and students are responsible for improving the achievement of this historical subject [1]. However, teachers the ones who play important role because they must be creative, innovative and resourceful in finding ideas to convey learning without being bored and making it easy for students to understand and indirectly enjoy a subject that is considered difficult and tedious. This is because, according to booth [2] [3], on the whole, quality students coming from effective teaching and learning processes.

According to the above situation, teachers must identify appropriate teaching methods and will indirectly change students' perceptions of this history subject. Teachers must be aware of the development of ICT in the educational world by fully applying information technology skills that they have in their title to create a more effective history of teaching and learning. Today, information and communication technologies are growing in the field of learning. For example, using Microsoft PowerPoint is a habit of teaching in the classroom. But this technology only places learners as a passive element in the learning process. Therefore, advanced technology is essential to produce interactive and effective learning processes.

One of the increasingly developed and expanded technology is the AR technology (Augmented Reality). AR is a visual technology that combines the virtual world object into the real-world view in real time [4] [5] [6]. In a simple word, AR is a virtual object that is shown in our smartphone camera view. Thus, AR has a very unique ability that can affect the learning session [7] [8] [9] [10].

Learning about history is an important subject in high school [11] and a teacher must be has a special approach so that students are interested in studying history [12] [13]. Homeland Warrior using AR system to learn about history of homeland warrior. It uses mobile application, it relates through the marker to display information about the warrior of homeland when camera is directing the marker. It uses mobile phone camera to scan the card that is generated as the marker. Image and information about the selected warrior then will be display on the screen. Homeland Warrior also have a best game through mobile application. This game function when user can guess who the warrior that related to description given. So that student can measure their understanding and enjoy the learning. With AR, students can get a whole new perspective on subject of history. It gives them the opportunity to get up close and personal like they never have before.

As stated in the background of the study, there are still some students who fail the subject of history very boring and difficult to understand. The problems that exist not only affect the student, but also impact on the teachers, schools and education in Malaysia. Researcher wish to develop an attractive and friendly-user augmented reality application as a learning aid. This application will cover on resident leaders fight in contradiction of the British topic in form 5 history subject. This app will help students improve their understanding and indirectly engage students in learning this subject.

The aim of this research is to develop a "Homeland Warrior" with augmented reality. When user use the marker that provided by pointing the marker toward the camera and revealing information and images about the fighter of homeland. User can also answer the question that have been provided and gift answers through markers that have been provided to measure the understanding and level of user memory.

\section{The literature review}

\subsection{Augmented Reality Technology}

Augmented reality (AR) is a combination of real and virtual objects in the real world, runs interactive in real-time, and has three-dimensional inter-object integration, virtual reality integrated with the real world. Integration of real and virtual objects is possible with appropriate display technology, interactivity enabled through specific input devices, and good integration requires effective tracking [4]. There are three principles of objective reality. The first is that AR is a combination of real-world 
and virtual, AR is interactive in real time, and there is a three-dimensional integration of objects, namely virtual objects integrated in the real world [5].

AR can be defined as a virtual environment in which virtual objects are added with computer technology integration. This technology can present user-friendly interactions, because with this technology users can experience virtual objects that are as real as the real world. AR systems have now been developed for various applications in education, including learning about technology [7] [14], 3D animation [15], healthy [16], and engineering [17].

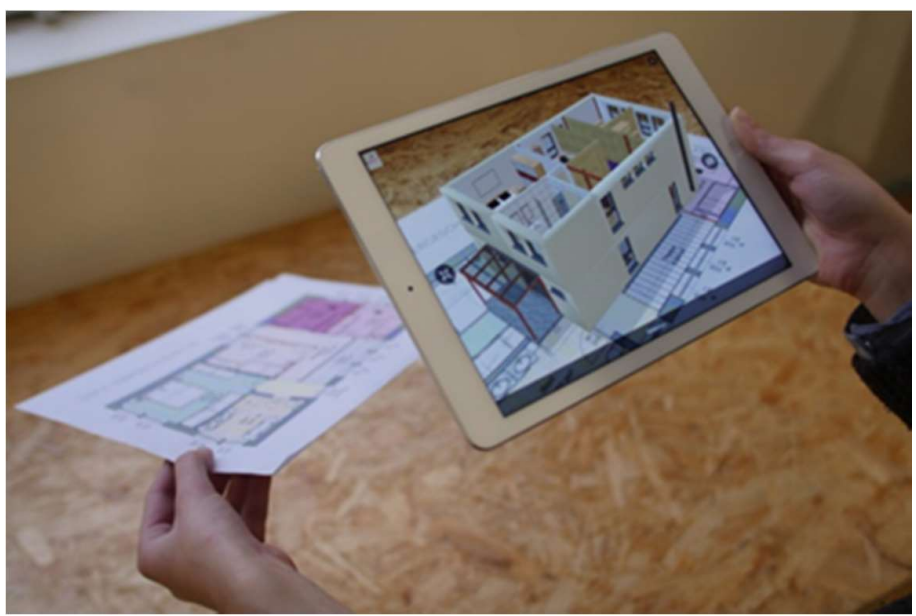

Figure 1. Augmented Reality Example

\subsection{History Subject}

History is a core subject for high school students embedded in the Secondary Integrated Curriculum (KBSM). History subjects contain many ideas abstract and abstract concepts [11]. This situation is affecting students it is difficult to properly grasp the concept of History. Facts have relate to concepts because facts are information or data that helps design, build and develop a concept [18].

History Education aims to foster and strengthen the spirit of loyalty nationality and identity as citizens of Malaysia and citizens of the world [11]. Through knowledge and appreciation of the history of homeland and country, students can understand the state of society and its relation to world history. History Education can also create a shared memory of History as a frame of reference international awareness and understanding [10]. The role of the subject is very much important in realizing the aspirations and aspirations of the country especially in the formation of a harmonious and harmonious society intellectually, spiritually, em can balance between material values and spiritual values and humanity.

\subsection{Development of Augmented Reality Technology in Education}

The world of educational technology has experienced rapid growth. These developments and changes involve not only philosophy and syllabus but also approaches and techniques teaching and learning [19]. It is also supported by Hashim [13] who says that innovative learning is a technology-based learning process that uses technology to facilitate student learning while teachers play the role of facilitators.

\subsection{Software Development Tools for Augmented Reality}

Many tools that can be used to develop AR Application. Android Studio was first announced at the Google I/O Conference in 2013 and released to the public in 2014. Prior to the birth of Android Studio, applications on Android were developed with the Eclipse IDE, the Java IDE. Having an open-source android studio can make it easier for those who want to create an app with Android Studio. Using Android Studio, you can easily create, edit and even test applications with just one Android Studio tool. The advantages of using Android Studio also give you access to the Android Software Development Kit (SDK). The SDK is a Java code extension that allows it to run smoothly on Android devices. For Java, it is required to write programs, the Android SDK is required to run programs on Android. So, by 
combining both, you need Android Studio. So, when you find a bug in your application, you can identify the bug by using Android Studio to fix it.

Other software development tool used by researchers is Vuforia. Vuforia is software that provides cross-platform for augmented reality (AR) application development, with robust recognition and performance for a wide range of tools including mobile and mixed reality devices that use Head Mounted Displays (HMD). Easily recognized by the computer technology used by Vuforia.

\subsection{Augmented Reality Marker}

Marker is need for display virtual objects in augmented reality and this marker is useful for telling applications, where virtual objects should be displayed. The form of marker can be 2D or 3D object. Some application using photos or real 3D objects as markers, other application uses a barcode or QR code as marker. In augmented reality application which used marker based, the marker must be registered before because the marker used as identity the place by application, to display the virtual object.

Figure 2 shows a flowchart for a simple augmented reality system. The capturing module captures the image from the camera. The tracking module calculates the correct location and orientation for virtual overlay. The rendering module combines the original image and the virtual components using the calculated pose and then renders the augmented image on the display [20].

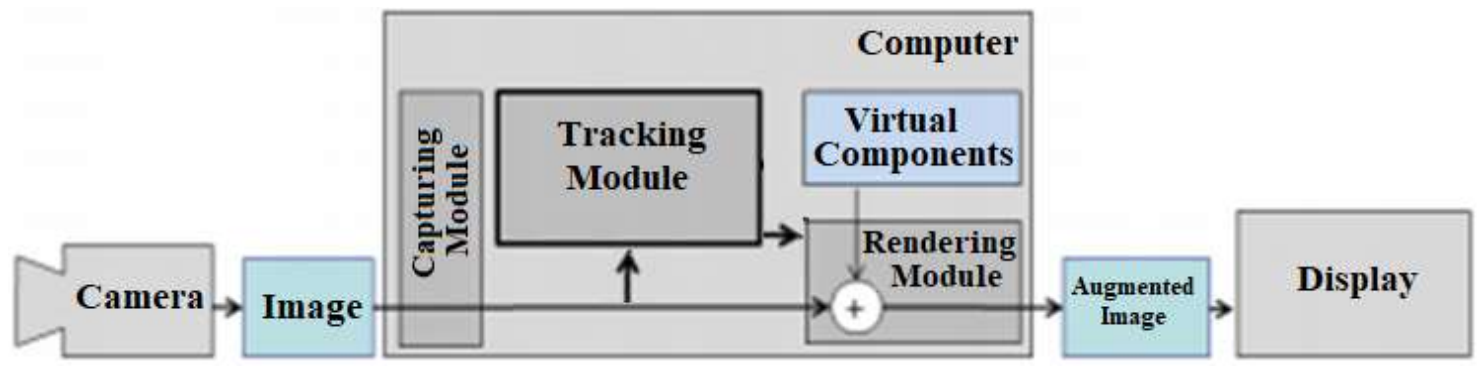

Figure 2. Flowchart for a Simple AR System

\subsection{Study of Existing Application}

\subsection{1. "AR Sejarah Pahlawan pada Uang Kertas" Application}

AR Sejarah Pahlawan pada Uang Kertas is an application that use Augmented Reality for learning the history of heroes. This application can be downloaded from Google Playstore for free from user device. This application suitable for all people as long as have a phone. This application use money to be a marker based. This application just simple application to describe about the heroes history. For using this application, user must scan the money using this application and user can see the detail and description about the warrior history.

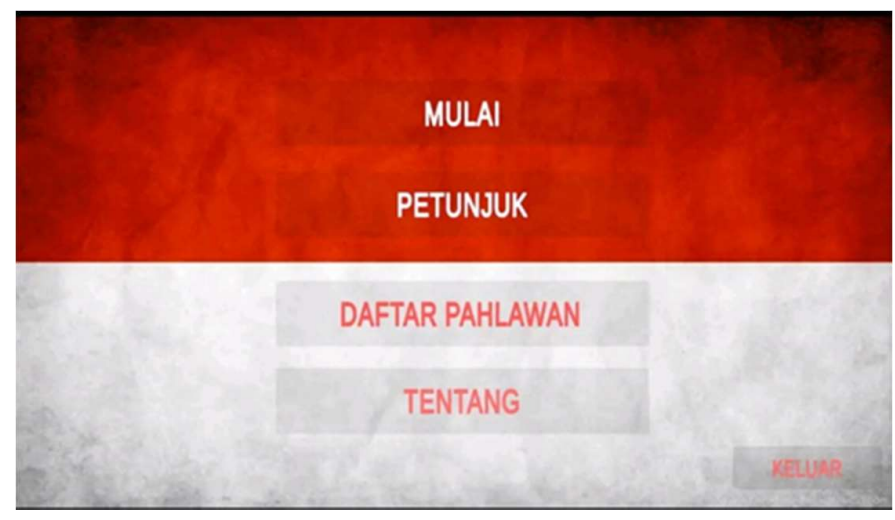

Figure 3. The Content of AR Sejarah Pahlawan pada Uang Kertas Application 


\subsubsection{AR DBP Sejarah Tingkatan 4 Application}

AR DBP Sejarah Tingkatan 4 an application that use Augmented Reality for Form 4 History textbook.
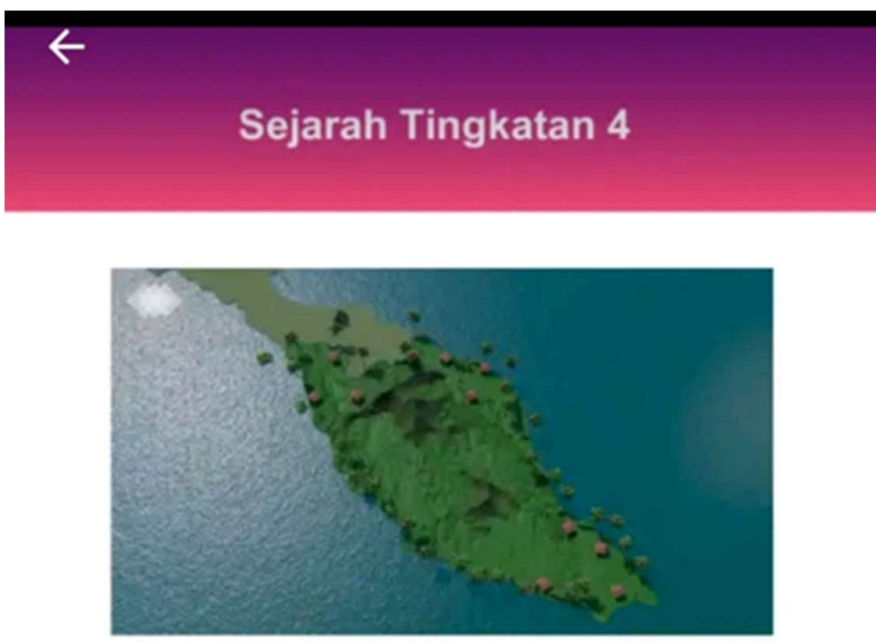

Serangan Jepun

di Tanah Melayu (M/S: 69)

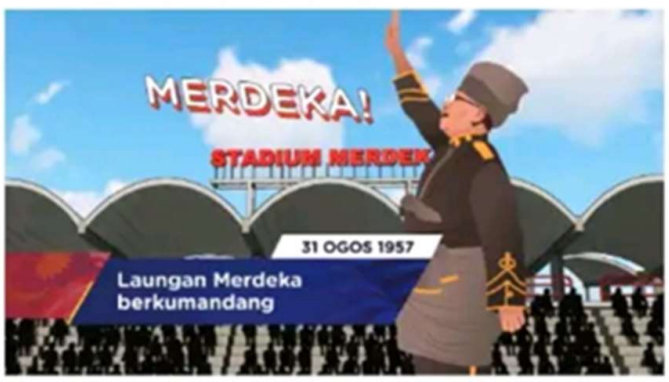

Peristiwa Kemerdekaan (M/S: 240)

\section{Panduan Penggunaan}

Figure 4. The Content for AR DBP Sejarah Tingkatan 4 Application

Where are:

1. This application can attract user witch use text book to more focus in study.

2. This application use book for the marked based.

3. This application easy and not difficult to understand it.

4. This application have choosen the topic from History textbook.

5. This application, can get for free when download from Google Playstore. 
Nur Ain Najihah Ibharim, Siti Zalifah Ramli, Siti Aishah Zahari, Nur Amalia Atikah Edyanto, Muhammad Asyraf Abdullah Zawawi

\subsection{Comparison of Existing Application and Homeland Warrior}

Table 1 shows the comparison between two applications that used for earlier studies.

Table 1. Comparison based on Characteristics

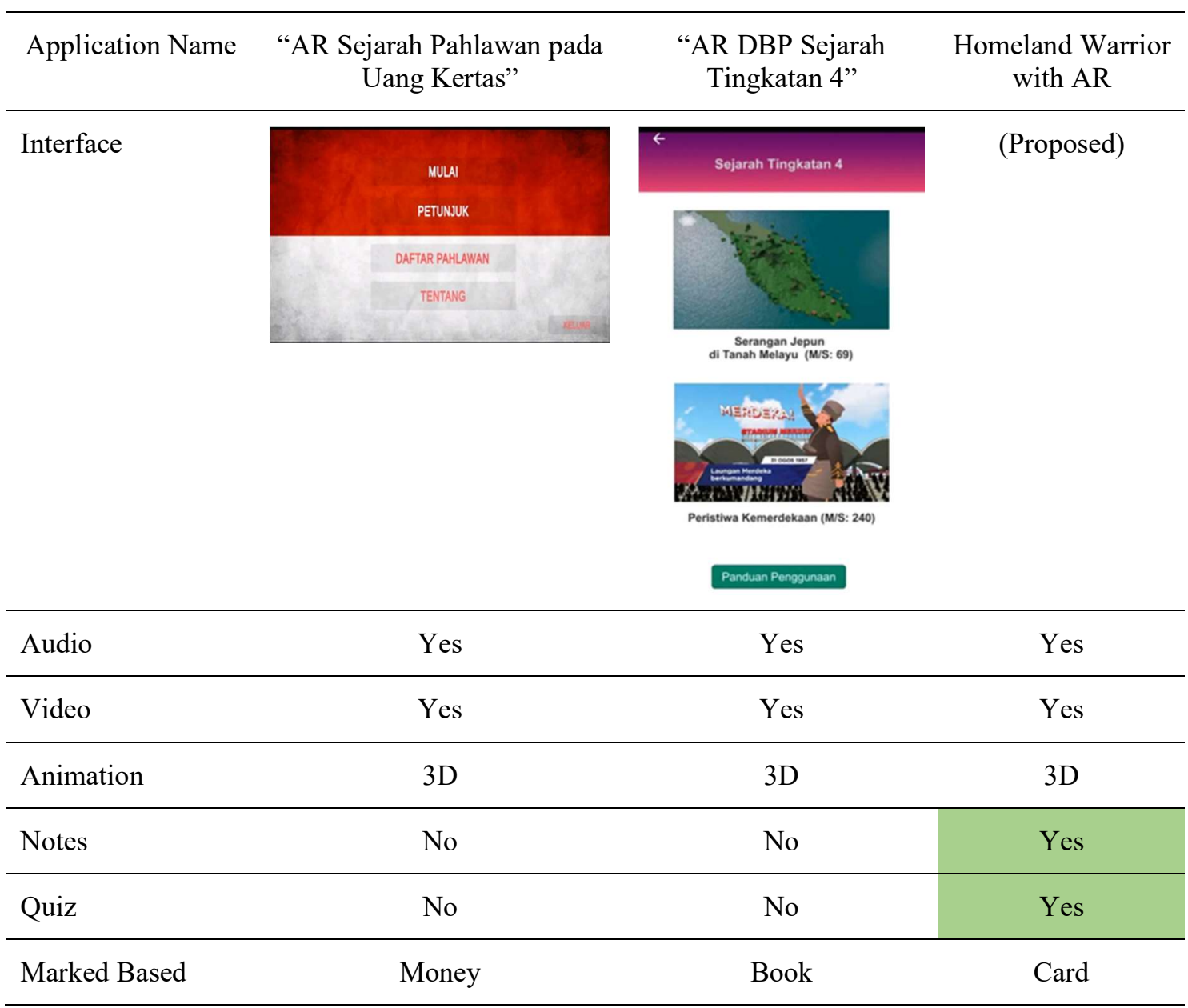

\section{Methodology}

Methodology is a systematic procedure that combines the adaptation of research and data analysis in line with its own rules to ensure the performance of research studies can be achieved well and perfectly.

Research methodology covers the methods, methods and approaches used to achieve the objectives and goals of a study. Therefore, in this chapter the researcher will discuss in detail about software development methodology that will be used in developing this research. The researcher will also discuss the method of study which is the background of the study sample, the data collection, the equipment to be used, the method of transcribing the data and the method of analyzing the data.

\subsection{Software Development Methodology}

In this study, the model chosen and used throughout the product development is ADDIE model. Researchers chose ADDIE model because Addie model is a systematic model which is provides a stepby-step sequence of events in teaching a learner. It is also associated with good quality design, with clearing learning objectives, specific structured content, integrated media and assessment strongly tied to desired learning outcomes. Besides, due to last phase of the ADDIE model, we can get all the feedback to keep on improving both skills and learner's experience. It is a model that allows design principles to be identified and implemented on a systematic and thorough basis. It is also a very useful 
Nur Ain Najihah Ibharim, Siti Zalifah Ramli, Siti Aishah Zahari, Nur Amalia Atikah Edyanto, Muhammad Asyraf Abdullah Zawawi.

management tool, allowing for the design and development of large numbers of courses to a standard high quality.

The ADDIE model is created by the Centre for Educational Technology at Florida State University. The ADDIE model developed by Dick and Cary in 1978 and Russell Watson revised in 1981, and was considered essential in the development of educational and training programs [18] [19]. This systematic process is represented in the acronym ADDIE, which stands for the important components in the process of creating the instructional design, which are:

- Analysis,

- Design,

- Development,

- Implementation,

- Evaluation.

Each phase in ADDIE model is related to and interacts with each other. The model gives you a streamlined, focused approach that provides feedback for continuous improvement. In general, the ADDIE model is as shown in Figure 5.

Table 2. The task of ADDIE Model [13]

\begin{tabular}{|c|c|}
\hline PHASES & TASKS \\
\hline \multirow[t]{3}{*}{ A (Analyse) } & Determining learning goals \\
\hline & $\begin{array}{l}\text { Analyze the learning materials } \\
\text { and background Analyze } \\
\text { teaching method }\end{array}$ \\
\hline & $\begin{array}{l}\text { Analyze related educational } \\
\text { games }\end{array}$ \\
\hline \multirow[t]{6}{*}{ D (Design) } & Design learning task \\
\hline & Sequences task classes \\
\hline & Set performance objectives \\
\hline & Design supportive information \\
\hline & Design procedural information \\
\hline & Design challenges and levels \\
\hline \multirow[t]{3}{*}{ D (Develop) } & Create artistic content \\
\hline & Program the game \\
\hline & Debug \\
\hline \multirow[t]{2}{*}{ I (Implement) } & Implement in test environment \\
\hline & $\begin{array}{l}\text { Implement in a teaching } \\
\text { environment }\end{array}$ \\
\hline \multirow[t]{3}{*}{ E (Evalution) } & Internal Testing \\
\hline & Public Testing \\
\hline & Gather Feedback \\
\hline
\end{tabular}

Figure 5 describes how the process will take place in designing this application based on ADDIE model theory. It shows that the ADDIE model formulates a comprehensive process of teaching design activities and this is a benefit to the ADDIE model compare to other models. The tasks of each phase are highlighted in Table 2. 


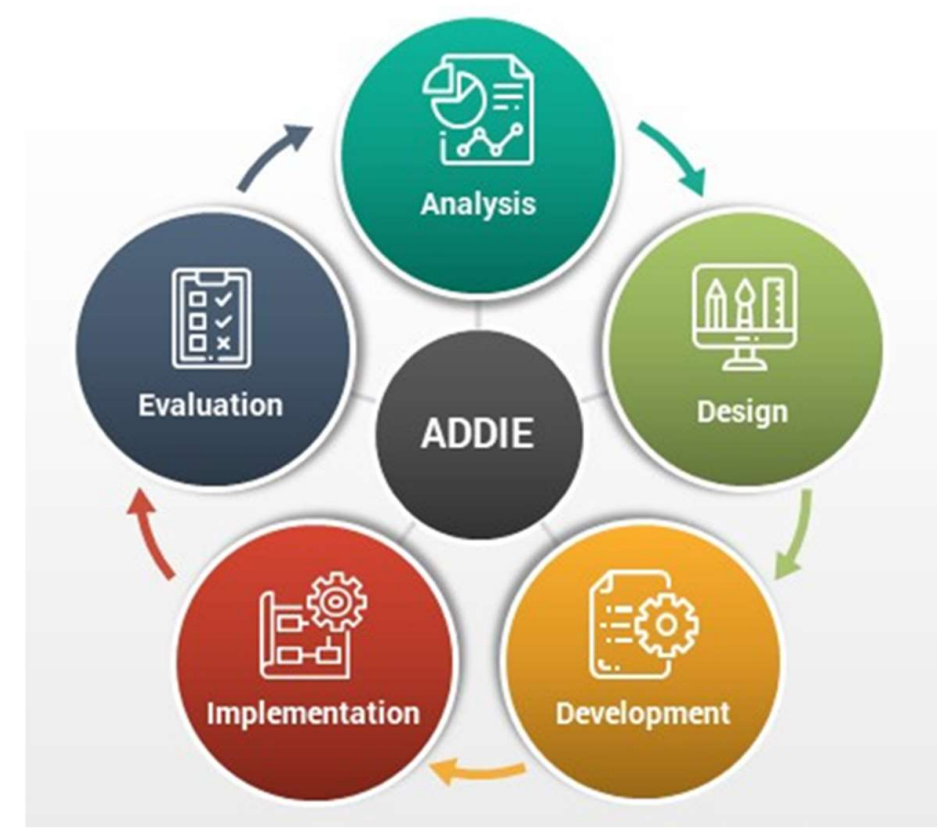

Figure 5. Process in Designing Based On the ADDIE Model Theory

\subsubsection{Analysis Phase}

Analysis is the first stage in the design of this AR application based on the phase in the ADDIE model. This phase is the description process of what is going to be taught and forms the basis of all other steps. In this phase, the researcher will analyze three main aspects like analysis of students, analysis of the learning environment and analysis of identifying teaching goals. There are several sub-activities in this phase of analysis, which will be analyzed before the next process is implemented. Some of the Sub activities that need to be analyzed first are setting objectives, defining user goals, identifying application content that meets the objectives, methods used to convey the teaching and learning process and finally software.

Some questions raised during the analysis process were carried out to obtain information related to the key aspects mentioned are:

1. Who is the target user that will use Homeland Warrior with AR?

2. What is the background of the user's knowledge of the homeland warrior?

3. To what extent are they proficient in understanding and remembering the history of the homeland warrior?

4. What is the significance of recognizing homeland warrior in the history subject?

5. What are the activities required in attracting interest to know and understand the history of the homeland warrior?

The answers to the following questions will be provided in the original sketch as a guide to designing this Homeland warrior with AR. The researcher will analyze step by step, starting with analyzing students until the next level. The questions in this phase will be asked to the history teacher for answers. The analysis of the tool that had been used in developing Homeland Warrior with AR is also conducted. Unity is one of the tools that will be use which is consist of Unity3D Packages. The suitable of tools that to be use in developing application of AR in multiple platform like PC, MAC, and Android.

\subsubsection{Design Phase}

Design phase is the next step in ADDIE model. The data obtained during the analysis phase is use to plan a strategy for developing the instruction in this phase and how the objective will be reached is clarified. In other words, in this phase have to consist of identifying the scope of the content, determine the usage of media and tools needed for media editing, and sketching that will occur within the content. 
Researcher use marked-based for develop Homeland Warrior wit AR. That means, that marker very importance and very needed, which could be an image and displayed on the screen. When the marker image is scanned using apps Homeland Warrior, the information or content is display and further interaction with the content could occur.

\subsubsection{Development Phase}

Development phase depends on the analysis phase and the design phase for guide on how the application AR look like. So that, if researcher did this phase correctly, the development will be easier. The development started with the marker image and develop apps to scan the marker. In this phase, the researcher will develop a real application by fulfilling the main aspect in developing an application that is the aspect of screen design which consists of several multimedia principles such as the principles of text, graphics, audio, animation, video and colour.

\subsubsection{Implementation Phase}

This phase is where the learning, training, processes, product and services are actually delivered to learners. This is means, this phase testing fully of the developed application of AR. This phase is carried out to determine whether the objective of the construction are achieved or not. Among the things tested is the functionality of each features. Each feature developed will tested its function. Testing performed in this phase is a reinforcement of the analysis and testing performed in the development phase.

There are two sub-tasks contained in the implementation phase:

1. Installation

After the marker an application for Homeland Warrior is fully developed, the researcher do the installation testing. The application will be installed on the device to test its technical errors and usability.

2. Run

The researcher will test every function in the application by using the complete application to ensure that there are no technical errors. Researcher must do a full analysis to ensure that the applications are effective in the teaching and learning process.

\subsubsection{Evaluation Phase}

Evaluation phase is the final process in ADDIE model. This phase very important to evaluate each step, in order to make sure the goals were archive using the instructional design and material to meet the learner needs. Users will be involved in this phase to assess the effectiveness, learning ability and satisfaction of students on the application.

Performance test will be conducted for user to find out the effectiveness of using the Homeland Warrior with AR for learning. Effectiveness assessment will use questionnaire techniques that look at various dimensions such as design, function, ease of use, learning ability, satisfaction, and future use. This questionnaire consists of five scales starting with scale one to strongly disagree, followed by the next number in sequence and ending with scale five scale to strongly agree. To test the level of effectiveness and satisfaction of the application, respondents will be given the opportunity to use this Homeland Warrior with AR first before answering the questionnaire.

\section{Conclusion}

This research was done with objectives to address the challenge in learning history topics. The author designs an application using Augmented Reality and use ADDIE model as a guide to develop the application. The method being used to evaluate the application is by using quantitative questionnaires.

\section{References}

[1] T. C. Brown, "The effect of verbal self-guidance training on collective efficacy and team performance," Personnel Psychology, vol. 56, no. 4, pp. 935-964, 2003.

[2] A. Booth, "Learning history in university: Student views on teaching and assessment," Studies in Higher Education, vol. 18, no. 2, pp. 227-235, 1993.

[3] N. H. Rahani, A. A. Bilong, M. R. Mat Suruji, and I. Y. Panessai, "Learning Logic Gates Using Augmented Reality", International Journal of Multimedia and Recent Innovation, vol. 2, no. 1, pp. 26-44, Mar. 2020. 
Nur Ain Najihah Ibharim, Siti Zalifah Ramli, Siti Aishah Zahari, Nur Amalia Atikah Edyanto, Muhammad Asyraf Abdullah Zawawi.

[4] R. T. Azuma, "A Survey of Augmented Reality," Presence: Teleoperators and Virtual Environments, vol. 6, no. 4, pp. 355-385, 1997.

[5] R. Azuma, Y. Baillot, R. Behringer, S. Feiner, S. Julier, and B. MacIntyre, "Recent advances in augmented reality," IEEE Computer Graphics and Applications, vol. 21, no. 6, pp. 34-47, 2001.

[6] J. Wither, Y.-T. Tsai, and R. Azuma, "Indirect augmented reality," Computers \& Graphics, vol. 35, no. 4, pp. 810-822, 2011.

[7] S. F. Sezali, A. M. Radzuan, N. I. Mohd Shabudin, and R. A. Afendi, "POCKET MALAYSIA: Learning about States in Malaysia Using Augmented Reality", International Journal of Multimedia and Recent Innovation, vol. 2, no. 1, pp. 45-59, Mar. 2020.

[8] Z. Aziz, and N. Jair, "Penggunaan peta konsep untuk meningkatkan pencapaian mata pelajaran sejarah bagi pelajar tingkatan dua," Jurnal Pendidikan Malaysia, vol. 34, no. 1, pp. 3-15, 2009.

[9] Z. Zainal Abidin and M. A. Abdullah Zawawi, "OOP-AR: Learn Object Oriented Programming Using Augmented Reality", International Journal of Multimedia and Recent Innovation, vol. 2, no. 1, pp. 60-75, Mar. 2020.

[10] A. Ahmad, S. H. Abd Rahman, and N. A. T. Abdullah, "Tahap keupayaan pengajaran guru sejarah dan hubungannya dengan pencapaian murid di sekolah berprestasi rendah," Jurnal Pendidikan Malaysia, vol. 34, no. 1, pp. 53-66, 2009, ISSN 0126-6020 / 2180-0782.

[11] Kementerian Pelajaran Malaysia, Sukatan Pelajaran Sejarah. Malaysia: Pusat Perkembangan Kurikulum, 2000.

[12] A. R. A. Rashid, Model dan pendekatan pengajaran sejarah KBSM. Kuala Lumpur: Dewan Bahasa dan Pustaka, 2000.

[13] Y. Hashim, Teaching using in Media for Education and Practise. Shah Alam: Penerbitan Fajar Bakti Sdn. Bhd, 1997.

[14] M. A. Ishak, M. R. Kosnan, and N. F. Zakaria, "Build IoT through Virtual Reality", International Journal of Multimedia and Recent Innovation, vol. 2, no. 1, pp. 11-25, Mar. 2020.

[15] S. N. S. Abu Samah, "The Efficacy of Augmented Reality on Student Achievement and Perception among Teluk Intan Community College Student in Learning 3D Animation", International Journal of Multimedia and Recent Innovation, vol. 2, no. 2, pp. 8795, Sep. 2020.

[16] N. Norhalim and A. Ismail, "An Early Development Process of an Augmented Reality-Based Healthy Diet Tool Prototype", International Journal of Multimedia and Recent Innovation, vol. 2, no. 2, pp. 96-101, Sep. 2020.

[17] G. Giraldi, R. L. S. Silva, P. S. Rodrigues, J. M. P. Júnior, and G. Cunha, "Augmented Reality for Engineering Applications: Dynamic Fusion of DataSets and Real World," in ISEMC International Symposium on Electromagnetic Compatibility, 2005.

[18] W. Hannum, "Instructional Systems Development: A 30 Year Retrospective," Educational Technology, vol. 45, no. 4, pp. 5-21, 2005.

[19] J. Jeuring, R. van Rooij, and N. Pronost, "The 5/10 Method: A Method for Designing Educational Games," Lecture Notes in Computer Science, pp. 364-369, Oct. 2014.

[20] S. Siltanen, "Theory and applications of marker-based augmented reality: Licentiate thesis," VTT Technical Research Centre of Finland, 2012. 